\title{
Recurrent Multiple Complex Anal Fan-Shape Fistula
}

Keywords: Fistulectomy; Anal fistula; Incontinence; Transsphincteric Abstract
Introduction: Fortunately, recurrent multiple complex anal fistula
is an uncommon pathology; however, it is at times frankly impossible
to cure and entails considerable fear regarding application of the
therapeutic option. Surgical techniques are varied, failure can have
fatal consequences, and experience is minimal.

Objective: Report the case of a patient with diagnosis of recurrent multiple complex anal fistula and his surgical treatment by classic fistulectomy and anal sphincter reconstruction.

Methods: Male patient, age 42 years, without significant history for the present condition, with presence of a single anal fistula of 12 years' evolution. First surgery with fistulotomy 3 years prior. Suffering relapse, with clinical classification of complex, patient was reoperated one year later, applying a seton on a single fistulous tract, reporting 2 additional tracts and biweekly adjustment for seven months without improvement. Patient was evaluated by our service, finding 5 secondary orifices with tracts of up to $12 \mathrm{~cm}$ from the edge of the anus, with a single primary tract in the $60^{\prime}$ clock sector at the level of the toothed line. Patient was subjected to surgical protocol, performing fistulectomy with complete section and plasty of the anal sphincter complex. Patient was diagnosed with recurrent transsphincteric complex "fan-shape" fistula with five fistulous processes, with satisfactory postoperative evolution, presenting complete healing and without sequelae.

Conclusions: Fistulectomy, although presently proscribed, is resolutive; it is believed to entail a high risk of incontinence, which can be avoided with precise anatomical knowledge and proper application of surgical technique.

\section{Introduction}

Recurrent multiple complex anal fistula is rare; at present there are no parameters for its classification, but three categories can be taken into consideration in describing complexity in a fistula:

1- Presents a high risk of fecal incontinence following surgical treatment.

2- The difficulty of the anatomical pathway and number of fistulous tracts.

3- Lack of healing or recurrence, i.e. reappearance more than once [1].

Upper transsphincteric fistulas involve the upper two thirds of the external sphincter and continue to pose a surgical challenge, due to possible incontinence resulting from muscular section involving more than one third of the sphincter [2].

To date we have not found an ideal treatment, with approaches divided in two main groups, those involving section of the sphincter and those that preserve them.

Treatment of recurrent multiple complex anal fistulas is highly controversial, with a large number of surgical approaches with equally varied outcomes, often poor and at times tenuous; some authors describe what they call "gold standard procedures" [3], which

\section{Journal of}

Clinical \& Medical Case Reports

\section{Morelos Adolfo Garcia Sanchez ${ }^{1 *}$, Mireya De La Fuente Gonzalez ${ }^{1}$, Alvaro Tomas Ruz Concha ${ }^{1}$ and Pablo Medina Garcia ${ }^{2}$}

${ }^{1}$ Dr. Gaudencio Gonzalez Garza General Hospital Specialized Medical Unit, La Raza National Medical Center, Mexico, USA ${ }^{2}$ Department of Health, Dr. Belisario Dominguez Specialized Hospital, Mexico, USA

\section{Address for Correspondence:}

Morelos Adolfo Garcia Sanchez, General Practitioner and Colonic and Rectal Surgeon, Dr. Gaudencio Gonzalez Garza General Hospital Specialized Medical Unit, Colonic and Rectal Surgery Service, La Raza National Medical Center, CP 02990. Mexico, USA, Tel: 01 (52) 55245900; E-mail: morelosadolfo@hotmail.com

Submission: 14 December 2015

Accepted: 12 January 2016

Published: 18 January 2016

Copyright: @ 2015 Garcia Sanchez, et al. This is an open access article distributed under the Creative Commons Attribution License, which permits unrestricted use, distribution, and reproduction in any medium, provided the original work is properly cited.

in fact may even include consulting-room procedures, such as the use of surgical tape.

Clinical manifestations in patients with recurrent multiple complex fistulas are: pruritus, constant discharge of purulent material, bleeding, serous fluid, and even fecal matter, all in small quantities. Most cases of this type of fistulas are painless or cause only minimal occasional pain, which allows patients a certain degree of quality of life, which accounts for their chronic nature and tolerance.

Performing the surgical technique or procedure with which we are most familiar is definitive, and is a decisive factor, and it is essential to have elements to support a proper diagnosis and plan the best possible course of treatment for each patient; in the literature, endoanal ultrasound is reported as a useful guide to planning a surgical strategy for each case [4]. On the other hand, nuclear magnetic resonance is a highly accurate parameter in surgery, which reduces recurrence up to $75 \%$ in patients and should be applied for this type of fistulas [5-7]. Even so, there is no guarantee of achieving a favorable outcome in a given patient.

\section{Objective}

Present the experience of a clinical case in a patient with recurrent multiple complex fistula with classic surgical management and repair of the entire anal sphincteric complex.

\section{Case Report}

Male patient, age 42 years, with genetic load for type 2 diabetes mellitus; 12 years smoking; and 10 years of alcohol use, often to the point of intoxication.

Twelve years ago, the patient developed a perianal abscess, with formation of a fistula 3 months later. He had his first surgery 3 years ago, undergoing a fistulotomy for a single anterior transsphincteric fistula $8 \mathrm{~cm}$ in length from the edge of the anus to the scrotum. He experienced a recurrence, and had further surgery one year later, 
classifying his condition as complex, on finding 3 fistulous tracts; the primary tract as described above, the left tract parallel originating in the same primary orifice in the 7 o'clock sector at $6 \mathrm{~cm}$ from the edge, and the right fistulous tract sharing the primary orifice with the others, in the $5 \mathrm{o}$ 'clock sector at a distance of $4 \mathrm{~cm}$ from the secondary orifice. A seton was inserted in the operating room under anesthesia, and tightened biweekly in the consulting room for 8 months with gradual shortening of the primary tract, but the patient experienced increasing pain and discharge of purulent matter, subsequently inserting a "cutting seton" in the operating room and under anesthesia, for the third time, with a "drainage seton" of silastic material, again with biweekly tightening for 3 months more, presenting similar clinical symptoms but adding gas and fluid incontinence.

The patient was admitted to this hospital and evaluated by our service, with proctologic exploration in Kraske's position finding: silastic seton, which, needless to say, was removed, identifying by rectal touch and anoscopy the primary orifice in the 6 o'clock sector below the toothed line, with intense fibrosis, and detecting 5 fistulous tracts, with a single primary tract and 5 secondary orifices varying from 12 $\mathrm{cm}$ long from the edge of the anus to the scrotum with secondary orifice at 6 o'clock, two right tracts $7 \mathrm{~cm}$ and $5 \mathrm{~cm}$ long from the edge of the anus to the perineum in the 4 and 5 o'clock sectors, and finally two left secondary orifices, $8 \mathrm{~cm}$ and $6 \mathrm{~cm}$ long respectively at 7 and 8 o'clock, from the edge of the anus (Figure 1). A fistulogram was taken, which was not conclusive; endoanal ultrasound was unavailable, with preoperative evaluation and clinical file complete, proceeding to surgical treatment with prior prophylactic antibiotic therapy and rectal preparation.

Surgical procedure: Under regional anesthesia in Kraske's position and with separation of the buttocks, rectal touch and anoscopy were performed. First, the primary orifice was identified, instilling oxygen peroxide in each of the secondary tracts, which are five in total, coinciding with a single primary orifice, stylets were inserted, performing fistulectomy Figure 2 of all the tracts and sectioning the entire sphincteric complex, extracting the fistulas. The involved muscles which were sectioned are: internal sphincter and external sphincter, subcutaneous, surface, and deep portions; Figure 3 finding five transsphincteric fistulas. Hemostasis was applied, separately continuing to repair the sphincteric bundles using 0 polyglycolic acid mattress sutures Figure 4 with subsequent "V-Y plasty", closure of the mucosa, and prior expanded cryptectomy, using 00 polyglycolic acids. Medical colostomy was maintained for 7 days, as well as supportive measures, with hospital discharge and follow-up in the consulting room for one year, with partial closure at 6 weeks and complete closure at 13 weeks, with continence corrected 100\%: control of solids, liquids, and even gases by Miller's classification. The patient remained asymptomatic for 8 months more, resulting in definitive release without sequelae (Figure 5).

\section{Discussion}

Recurrent multiple complex fistulous disease, which in this case we have referred to as "FAN-SHAPE FISTULA," is extremely rare; at present management is a challenge, and therefore highly controversial. There is no proper definition for complex anal fistula, and much less a standardized treatment as a practical guide for its resolution. A common denominator in this kind of pathology, which can be a lethal feature, is that it can compromise the entire sphincteric complex, for which reason it inspires such fear [1].
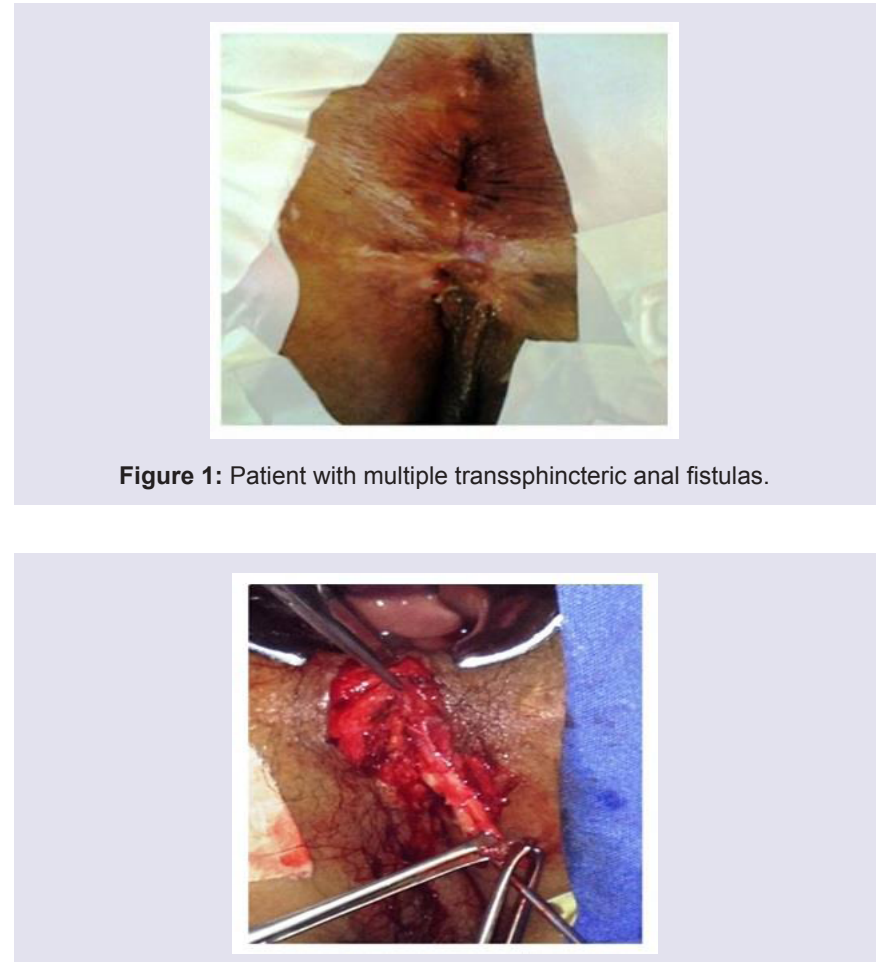

Figure 2: Fistulectomy: fistulous tract skeletonized along its full length below the sphincteric complex.

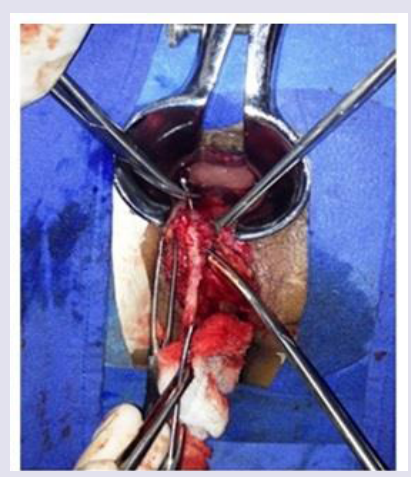

Figure 3: Fistulectomy: cutting of anal muscles of the entire sphincteric complex with skeletonized fistula.

There are published accounts of experiences with satisfactory outcomes, involving fistulectomy and reconstruction of the sphincter with up to 14 years' follow-up, with average healing time of 4 weeks and an $88 \%$ success rate, as well as second operations with a rate of healing of up to $100 \%$ [8].

Other reports indicate that fistulotomy with reconstruction of the sphincter may be an effective option in recurrent complex anal fistula, with a $75 \%$ success rate and $25 \%$ sequelae of anal incontinence $[9,10]$.

Also, a comparative study of fistulotomy with sphincter repair and the advancement flap surgical technique, the results were similar, both with 7.4 and $7.1 \%$ recurrence respectively, as well as in continence [11]. 


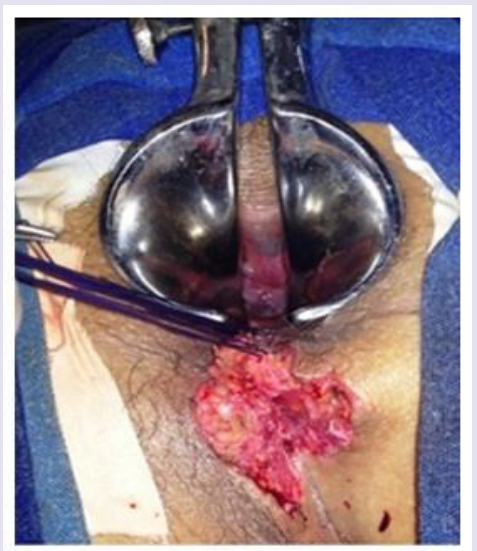

Figure 4: Anal sphincteroplasty: repair of the entire sphincteric complex with mattress sutures on the entire sphincteric complex.

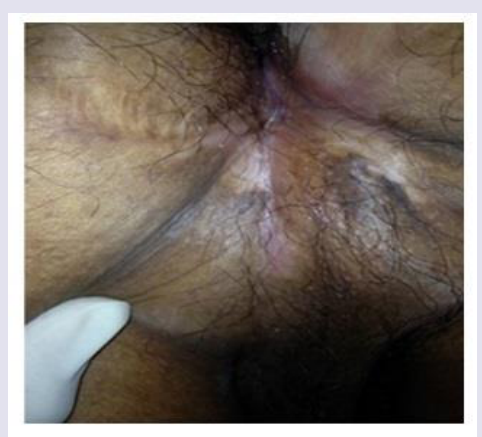

Figure 5: The same patient 13 weeks later with scarring and complete healing, with minimal deformity and with no recurrence.

Surgery for anal fistulas with excision and advancement flap repair has a very high rate of recurrence, of up to $55 \%$ [12-14].

The Surgisis biological plug, which in theory produces closure of the fistula in approximately 12 weeks, without surgery, by replacing the fistulous tract with the patient's own cells, has received fairly optimistic reviews; however, European experience reports success rates of only $41 \%$; in conclusion, this kind of technique, is used for complex anal fistulas, is safe, with more or less acceptable rate of effectiveness, and does not produce fecal incontinence [15-17]. An overall rate of success in the range of 31 to $60 \%$ has been reported with application of fibrin, as an alternative to conventional surgery and in patients with serious associated diseases $[18,19]$.

It is important to mention Hanley's sphincter preserving fistulectomy technique, which in recent years has reported a success rate of up to $100 \%$, but clear criteria must be used in choosing this surgical approach, as it is not indicated in all complex fistulas; in a patient with a horseshoe crossing the puborectal bundle, it is unquestionably the clearest indication $[1,20,21]$.

The Anal fistulas by ligation of the fistulous tract in recent years; this sphincter preserving technique was first described by Rojanasakul in the year 2007 [22]. New studies reveal a success rate of only $50 \%$ [23].
There are other, newer techniques, among them autologous fibrin enriched with Vivostat platelet-derived factors, rich in growth factors, which are involved in the inflammatory process and in tissue repair, with reported recurrence of only $10 \%$ and without complications of incontinence [24].

On the other hand, application of autologous stem cells derived from adipose tissue in complex anorectal fistulas represents a new approach to improve regeneration and/or repair of damaged tissues, accelerating wound healing, with a reported $57.1 \%$ success rate, which is quite promising [25].

Finally, we will discuss the use of setons in their three modes: cutting, guide, and drainage [26]. Is it even a surgical technique? Is it a good alternative? Is it cost-effective? Is it a valid procedure today, after 25 centuries in existence?

This millenarian technique, which several authors still consider the gold standard of treatment for complex fistulas [3,27]. Reports are variable, indicating a success rate of only $32.6 \%$ with a significant casuistry of up to 232 patients [28], in contrast with another report on only 31 cases, which presents recurrence in 3 patients with a $79 \%$ success rate, with mean seton permanence of 7 months and 10 postoperative consultations to tighten it. However, up to $16 \%$ of patients experience some degree of anal incontinence with this option. [27,29,30]

It is important to mention that the objective of surgical treatment of anal fistula is to eradicate the suppurative process without compromising anal continence [31]; therefore, essential concepts which we need to check are as follows:

1- It is important to identify the primary orifice or orifices of an anorectal fistula, resect them, and perform cryptectomy.

2- The resultant routine use of oxygen peroxide as a means of identifying the primary orifice intraoperatively.

3- The belief that partial cutting of the internal and external sphincter may cause varying degrees of incontinence, or that complete section of the sphincteric apparatus may give rise to total fecal incontinence, is a myth, such outcomes are possible, needless to say, if proper repair is not achieved. Muscular bundles such as: the internal anal sphincter and the external anal sphincter in its three portions, in anterior fistulas, are repaired without sequelae, with the exception of posterior fistulas which involve the puborectal bundle.

4- The only muscle which should never be sectioned is the puborectal bundle.

5- It is important to identify the tract, or multiple tracts, of an anorectal fistula (its specific mapping or as accurate as possible), blind abscesses, with single or multiple orifice; perform a single fistulectomy in the initial surgery and if there is a second fistula, leave it for a second surgical time.

6- Proper use of the appropriate suture is invaluable; the current obsolete application of chromic catgut which has considerable disadvantages and cannot be compared with polyglycolic acid, due to the advantages of the latter, such as: greater strength, longer lasting tensile strength, better maneuverability, and less inflammatory reaction in tissues, and as a result less postoperative pain for patients. 
Citation: Garcia Sanchez MA, De La Fuente Gonzalez M, Ruz Concha AT, Garcia PM. Recurrent Multiple Complex Anal Fan-Shape Fistula. J Clin Med Case Reports. 2016;3(1): 4.

ISSN: $2332-4120$

7- In the case of muscular section of the puborectal bundle with total fecal incontinence, subsequent repair using the Parks technique is necessary, for which good results are reported, of up to $80 \%$, rather than use of colostomy as last recourse $[16,32,33]$.

As regards incontinence, in general, results from various studies involving all kinds of fistulas, regardless of treatment, have reported indices of incontinence with widely ranging figures, from 10 to $45 \%$ of cases [34].

\section{Conclusions}

Fistulectomy, although presently proscribed, is resolutive; it is believed to entail a high risk of incontinence, which can be avoided with precise anatomical knowledge and proper application of surgical technique.

\section{References}

1. Garcia-Sanchez MA, Medina-Garcia P, Avila-Carrillo GM, Parra Hernández DL, Reyes Pérez AS, et al. (2012) Tratamiento quirúrgico de la fistula anorrectal compleja en herradura. Rev Trau Amer Lat 2: 11-15.

2. Chung W, Kasem P, Ko D, Sun C, Brown CJ, et al. (2009) Tratamientos para la fístula perianal: Plug para fistula anal y adhesivo de fibrina versus tratamiento convencional en la reparación de las fistulas perianales complejas. Am J Surg 197: 604-608

3. Memon AA, Murtaza G, Azami R, Zafar H, Chawla T, et al. (2011) Treatmen of complex fistula in ano with cable-tie seton: a prospective case series. ISRN Surg 2011: 636952.

4. Fernandez-Frias AM, Perez-Vicente F, Arroyo A, Sánchez-Romero AM, Navarro JM, et al. (2006) Is anal endosonography useful in the study of recurrent complex fistula-in-ano? Rev Esp Enferm Dig 98: 573-581.

5. Buchanan G, Halligan S, Williams A, Cohen CR, Tarroni D, et al. (2002) Effect of MRI on clinical outcome of recurrent fistula-in-ano. Lancet 360: 1661-1662.

6. Cuenod CA, de Parades V, Siauve N, Marteau P, Grataloup C, et al. (2003) MR imaging of ano-perineal suppurations. J Radiol 84(4 Pt 2): 516-528.

7. Gustafsson UM, Kahvecioglu B, Astrom G, Ahlström H, Graf W (2001) Endoanal ultrasound or magnetic resonance imaging for preoperative assessment of anal fistula: a comparative study. Colorectal Dis 3: 189-197.

8. Jivapaisarnpong P (2009) Core out fistulectomy, anal sphinchter reconstruction and primary repair of internal opening in the treatment of complex anal fistula. J Med Assoc Thai 92: 638-642.

9. Perez F, Arroyo A, Serrano P, Candela F, Sanchez A, et al. (2005) Fistulotomy with primary sphincter reconstruction in the management of complex fistula-in-ano: prospective study of clinical and manometric results. J Am Coll Surg 200: 897-903.

10. Perez F, Arroyo A, Serrano P, Candela F, Perez MT, et al. (2006) Prospective clinical and manometric study of fistulotomy with primary sphincter reconstruction in the management of recurrent complex fistula-in-ano. Int $J$ Colorectal Dis 21: $522-526$

11. Perez F, Arroyo A, Serrano P, Sánchez A, Candela F, et al. (2006) Randomized clinical and manometric study of advancement flap versus fistulotomy with sphincter reconstruction in the management of complex fistula-in-ano. Am J Surg 192: 34-40.

12. Gustafsson UM, Graf W (2002) Excision of anal fistula with closure of the internal opening: functional and manometric results. Dis Colon Rectum 45 1672-1678.

13. Kreis ME, Jehle EC, Ohlemann M, Becker HD, Starlinger MJ (1998) Functional results after transanal rectal advancement flap repair of transsphincteric fistula. Br J Surg 85: 240-242.

14. Schouten WR, Zimmerman DD, Briel JW (1999) Transanal advancement flap repair transsphincteric fistulas. Dis Colon Rectum 42: 1419-1422.

15. Deeba S, Aziz O, Sains PS, Darzi A (2008) Fistula-in-ano: advances in treatment. Am J Surg 196: 95-99.

16. Perez-Lara FJ, Marin-Moya R, del Rey-Moreno A, Oliva Muñoz (2013) Fistula perianal de origen criptoglandular ¿qué hay de nuevo? Cir Andal 24: 39-45.

17. Borda-Maderas LA, Chiroque-Benitez L, Pinto-Elera JO, Manzaneda Pineda AJ (2011) Experiencia con el tapon biologico para fistula anal compleja. Rev Gastroenterol Peru 31: 345-350.

18. Venkatesh KS, Ramanujam $P$ (1999) Fibrin glue application in the treatment of recurrent anorectal fistulas. Dis Colon Rectum 42: 1136-1139.

19. Loungnarath R, Dietz DW, Mutch MG, Birnbaum EH, Kodner IJ, et al. (2004) Fibrin glue treatment of complex anal fistulas has low success rate. Dis Colon Rectum 47: 432-436.

20. Hanley PH (1965) Conservative surgical correction of horseshoe abscess and fistula. Dis Colon Rectum 8: 364-368.

21. Hanley PH, Ray JE, Pennintong EE, Grablowsky OM (1976) Fistula-in-ano: a ten-year follow-up study of horseshoe-abscess fistula in-ano. Dis Colon Rectum 19: 507-515.

22. Rojanasakul A, Pattanaarun J, Sahakitrungruang C, Tantiphlachiva K (2007) Total anal sphincter saving technique for fistula-in-ano; the ligation of intersphincteric fistula tract. J Med Assoc Thai 90: 581-586.

23. Gutierrez-Perez JO, Villanueva-Herrero JA, Jimenez-Bobadilla B, Velasco García PS (2012) Tratamiento de la fistula anal mediante ligadura de trayecto fistuloso en el espacio interesfinterico con poliglactina 2-0. Estudio piloto. Cir Gen 34: 111-115.

24. van der Hagen SJ, Baeten CG, Soeters PB, van Gemert WG (2011) Autologous platelet-derived growth factors (platelet-rich plasma) as an adjunct to mucosal advancement flap in high cryptoglandular perianal fistulae: a pilot study. Colorectal Dis 13: 215-218.

25. Herreros MD, Garcia-Arranz M, Guadalajara H, De-La-Quintana P, GarciaOlmo D, et al. (2012) Autologous expanded adipose-derived stem cells for the treatment of complex cryptoglandular perianal fistulas: a phase III randomized clinical trial (FATT1: fistula Advanced Therapy Trial 1) and longterm evaluation. Dis Colon Rectum 55: 762-772.

26. Cosman BC (1998) All's well that ends well: shakespeare's treatment of ana fistula. Dis Colon Rectum 41: 914-924.

27. Charúa-Guindic L, Méndez-Morán MA, Avendaño-Espinosa O, JiménezBobadilla B, Charúa-Levy E (2007) Seton de corte en el tratamiento de la fistula anal compleja. Cir Ciruj 75: 351-356.

28. Chung W, Kazemi P, Ko D, Sun C, Brown CJ, et al. (2009) Anal Fistula plug and fibrin glue versus conventional treatment in repair of complex anal fistulas. Am J Surg 197: 604-608.

29. Giordano M, Rebesco B, Blanco G, Torelli I (2003) Surgical treatment of anal fistulas. Personal experience on 1,000 patients over a 20 -year period. Minerva Chir 58: 57-65.

30. Joy HA, Williams JG (2002) The outcome of surgery for complex anal fistula. Colorectal Dis 4: 254-261

31. Garcia-Aguilar J, Belmonte C, Wong WD, Goldberg SM, Madoff RD (1996) Anal fistula surgery. Factors associated with recurrence and incontinence. Dis Colon Rectum 39: 723-729.

32. Re H, Guala AA, Francia HJ (1990) Infecciones necrotizantes de partes blandas. Rev Argent Cirugia 59: 118-122.

33. Barreiro C, Leiro F (2009) Abscesos y fistulas perianales. Cirugia Digestiva III: 1-11.

34. Navarro A, Marc M, Garcia-Domingo MI, Gómez R, Marco C (2004) Diagnóstico y tratamiento de las fistulas anorrectales complejas. Cir Esp 76: 142-148. 